\title{
Customer-Bank Communication Terminals and the McFadden Act Definition of a "Branch Bank"
}

\author{
On December 12, 1974, the Comptroller of the Currency, James \\ E. Smith, issued a ruling and opinion ${ }^{1}$ allowing national banks
}

1. 39 Fed. Reg. 44416 (1974) [hereinafter cited as Comptroller's Opinion]. The ruling, which will be codified at 12 C.F.R. $\$ 7.7491$, is as follows:

A national bank may make available for use by its customers one or more electronic derices or machines through which the customer may communicate to the bank a request to withdraw money either from his account or from a previously authorized line of credit, or an instruction to receive or transfer funds for the customer's benefit. The device may receive or dispense cash in accordance with such a request or instruction, subject to verification by the bank. Such devices may be unmanned or manned by a bona fide third party under contract to the bank. The bank for a reasonable period of time may provide one of its employees to instruct and assist customers in the operation of the device. Any transactions initiated by such a device shall be subject to verification by the bank either by direct wire transmission or otherwise.

Use of such devices at locations other than the main office or a branch office of the bank does not constitute branch banking. A bank may provide insurance protection under its bonding program for transactions involving such devices.

The establishment and use of these devices is subject to the following limitations:

(a) Written notice must be given to the Comptroller's Office and to the office of the appropriate regional administrator 30 days before any such device is put into operation. Such notice shall describe with regard to the device or machine:

(1) the location;

(2) a general description of the area where located (e.g., shopping center, gasoline station, supermarket) and the manner of installation (e.g., free standing, exterior wall, separate interior booth);

(3) the manner of operation, including whether the device is on-line;

(4) the kinds of transactions which will be performed;

(5) whether the device will be manned, and, if so, by whose employee;

(6) whether the device will be shared, and, if so, under what terms and with what other institutions and their location;

(7) the manufacturer and, if owned, the purchase price or, if leased, the lease payments and the name of the lessor;

(8) the distance from the nearest banking office and from the nearest similar device of the reporting bank; and

(9) the distance from the nearest banking office and nearest similar device of another commercial bank, which will not share the facility, and the name of such other bank or banks.

(b) National banks are urged prior to July 1, 1975, not to establish a CBCT in any state in which state law would prohibit a state chartered bank from establishing a similar facility.

(c) To the extent consistent with the antitrust laws, national banks are permitted, but not required, to share such devices with one or more other financial institutions.

39 Fed. Reg. at 44420-21. 
to install off-premises "customer-bank communication terminals" (CBCTs) without regard to state restrictions on branch banking. ${ }^{2}$ Activated by specially encoded customer identification or bank credit cards, these terminals can be used to withdraw cash from or make deposits to a checking or savings account, to authorize payments to third parties, and to obtain cash under prearranged lines of credit. $^{3}$ The impact of this technological innovation on banking practices will depend in large measure on what legal constraints, if any, are imposed. If regulations restrict installation of CBCTs to bank premises, the potential impact will be limited to extending business hours at the banking house. On the other hand, if officials allow these terminals to be installed in shopping centers and retail stores on a widespread basis, the CBCT may revolutionize the bank-customer relationship by dramatically increasing convenient access to basic banking services. This shift may, in turn, be part of more widespread changes. Plans are under way for a nationwide "electronic payments system" that, if completed, will largely replace the current system of paper checks with a network of computers and on-line terminals transferring funds instantaneously by means of electronic impulses. ${ }^{4}$

A major barrier to the installation of CBCTs at off-premises locations is the potential applicability of state branch banking restrictions. Although as a general rule corporate powers of na-

2. Two cases questioning the validity of the Comptroller's rulings are now pending. Missouri ex rel. Kostman r. First Nat'l Bank in St. Louis, filed, No. 49456F(3), Cir. Ct. Mo., Jan. 6, 1975, removed and filed, Civil No. 113C(1), E.D. Mo., Feb. 18, 1975, concerns two on-line customer-operated CBCTs located outside the city in which the main bank is located, but in the adjacent county. Independent Bankers Ass'n of America v. Smith, filed, Civil No. 0089, D.D.C., Jan. 17, 1975, is an action for a declaratory judgment that the Comptroller's ruling is invalid and for an injunction to stay the implementation of the ruling.

3. The equipment can be either on-line, that is, directly linked to the bank's computer, or off-line. If it is an off-line facility, tapes recording the day's transactions must be collected periodically and brought to the bank. Also, CBCTs can be customeroperated (unmanned) or they can be operated by an employee of the store or other location in which the terminal is located. In either case, the customer's card is inserted into the terminal and buttons are pushed on a console to indicate the nature of the transaction. A customer-operated terminal will dispense cash and receive deposits directly. A store-operated terminal will communicate information and initiate transfers of funds. See Comptroller's Opinion at 44417; text and notes at notes 28-39 infra.

4. The essence of the projected electronic payments system is simultaneous crediting of a payee's account and debiting of a payor's account. 58 FED. REs. BuLL. 1009 (1972). It is anticipated that this system will have two major components: (1) automatic transfers of recurring payments, such as wages, dividends, annuities, social security benefits, rental obligations, and insurance premiums; and (2) transfers of nonrecurring payments through CBCTs. See 59 FEd. Res. Bull. 874 (1973). See also Survey: Touad a Less-Check Society, 47 Notre DaMe Law. 1163 (1972); note 122 infra. 
tional banks are not limited by state law, ${ }^{5}$ the McFadden $\mathrm{Act}^{6}$ authorizes national banks to establish branches only to the extent that state banks are allowed to do so by state law. ${ }^{7}$ If CBCTs are held to be "branches" within the meaning of the McFadden Act, state restrictions on branching could inhibit the development of CBCTs within the national banking system. Currently, twelve states prohibit branching altogether, ${ }^{8}$ twenty-one allow it within a limited geographical area, ${ }^{9}$ and eighteen allow statewide branching. ${ }^{10}$ Even where branching is allowed, moreover, states impose certain statutory conditions: typically the branch must meet minimum capital requirements, and its location must maximize convenience to the public without invading another bank's service area. ${ }^{11} \mathrm{Al}-$

5. See text and notes at notes 100-03 infra.

6. Act of Feb. 25, 1927, ch. 191, 44 Stat. 1224 (codified at 12 U.S.C. §§ 36, 332 (1970)).

7. 12 U.S.C. $\& 36(1970)$.

8. See Colo. Rev. Stat. Ann. \& 14-3-1 (Supp. 1973); Fla. Stat. Ann. § 659.06 (Supp. 1974); Ill. Rev. Stat. ch. 161/2, § 106 (1973); Kan. Stat. AnN. § 9-1111 (Supp. 1974); Minn. Stat. AnN. \& 48.34 (1970); Mo. Ann. Stat. § 362.105 (1968); Mont. Rev. Codes Ann. § 5-1028 (1968); Neb. Rev. Stat. \$ 8-157 (Supp. 1974); OkLa. Stat. AnN. tit. 6, \& 2061 (1966); Tex. Rev. Crv. Stats. art. 342-903 (1973); W. VA. Code ANN. \& 31A-8-12 (1972). Wyoming, another state without branching, has no statutory provision. 1 CCH FED. BANKING L. REP. If 3106 (1973).

9. Three states restrict their branches functionally as well as geographically: ARk. Stats. AnN. \$ 67-340 (Supp. 1973); N.D. Cent. Code \$ 6-03-14 (Supp. 1973) (allowing only teller facilities); IowA CODE ANN. $\$ 524.1201$ (Supp. 1974) (allowing branch offices to perform banking services for customers but not executive and recordkeeping activities). The other limited branching states are: ALA. CoDE tit. 5, § 125(1) (1960); Ga. Code ANn. § 13-203.1 (Supp. 1974); HawaII Rev. Laws § 403-53 (1968); Ind. Ann. Stat. § 28-1-17-1 (1973); Ky. Rev. Stat. AnN. \$ 287.180 (1972); La. Rev. Stat. Ann. § 6:54 (1951); Mass. Ann. Laws ch. 172A, § 12 (Supp. 1974); Мich. Сomp. Laws Ans. § 487.471 (Supp. 1974); Miss. Code AnN. § 81-7-7 (1972); N.H. Rev. Stat. ANN. § 384-B:2 (1968); N.M. STAT. ANN. § 48-2-17 (1966); N.Y. Banking Law § 105 (McKinney Supp. 1974); OHro Rev. Code § 1111.02-.03 (Supp. 1973); Pa. Stat. AnN. tit. 7, § 904 (Supp. 1974); Tenn. Code AnN. § $45-443$ (Supp. 1974); UTah Code ANN. § 7-3-6 (1971); VA. Code ANn. $\$ 6.1-39$ (Supp. 1974); Wis. Stat. ANn. § 221.04 (1974).

10. Alaska Stat. \$ 06.05.415 (1962); Ariz. Rev. Stat. AnN. \$ 6-190 (1974); Cal. Fin. Code $\S 500$ (West 1968); Conn. Gen. Stat. Ann. § $36-59$ (Supp. 1975); Del. Code ANn. tit. 5, § 770 (Supp. 1970); D.C. Code ENCYCL. ANN. \$ 26-103(b) (1967); Idaho Code § 26-1001 (1968); Me. Rev. Stat. ANN. tit. 9, 442 (1964); MD. ANN. Code art. 11, § 65 (1968); Nev. Rev. Stat. § 660.015 (1973); N.J. Rev. Stat. ĀnN. § 17:9A-19 (Supp. 1974); N.C. GeN. Stat. § 53-62 (Supp. 1974); Ore. Rev. Stat. \$§ 714.030-.170 (1973); R.I. Gen. LAws ANN. \& 19-1-13 (1968); S.C. Code ANN. \$ 8-57 (1962); S.D. Compiled Laws Ann. § 51-20-1 (Supp. 1974); Vt. Stat. Ann. tit. 8, § 651 (1971); Wash. Rev. Code Ann. 30.40 .020 (Supp. 1974).

11. Illustrative of the difficulties of applying traditional branch banking laws to CBCTs is Independent Bankers of Oregon v. Camp, 357 F. Supp. 1352 (D. Ore. 1973). In that case, the Comptroller authorized an Oregon national bank to install two customer-operated CBCTs activated by specially coded BankAmericards. All parties to the case agreed that the CBCTs were to be considered branches, but the Oregon 
though the Comptroller has the responsibility of deciding whether or not a given national bank may branch, he must adopt the state's conditions for branching. ${ }^{12}$ Thus, even if all the states were to amend their laws to specifically allow CBCTs, characterizing the terminals as branches would still subject the national banks' CBCTs to whatever regulatory strings the individual states chose to attach. $^{13}$

If the CBCTs are held not to be "branches" under the McFadden Act, however, federal authorities will have the sole power to regulate their use by national banks. Federal control would probably be more permissive than this state control. In his December 1974 ruling, for example, the Comptroller stated that he would allow national banks the "widest latitude" to experiment with and develop CBCT systems. ${ }^{14}$ The decision reflected his belief that expanded CBCT use would promote customer convenience, ${ }^{15}$ the development of

Superintendent of Banks argued that they were not the type of branches authorized by the state statute. Besides geographical and capital restrictions, the statute imposed requirements wholly inapplicable to CBCTs, such as periodic reporting of deposits received and retained, as well as payment of an examination fee for a state audit of the branch's books. Without fully accepting the Superintendent's position, the court held the CBCTs in question to be improperly authorized, because, being limited to a very small class of users, they did not meet the state's statutory test of serving the public convenience and advantage. Oregon has since amended its law to specifically allow CBCTs. See note 13 infra.

12. First Nat'l Bank of Logan v. Walker Bank \& Trust Co., 385 U.S. 252 (1966), discussed in text and notes at notes 63-67 infra.

13. Three states currently have laws specifically dealing with CBCTs. Oregon allows banks to establish four "automated banking facilities" without geographic restriction, an apparently unlimited number on the premises of a bank or authorized branch, and a limited number (determined by the Superintendent of Banks) within one hundred yards of a bank or branch. All off-premises equipment must, however, be unmanned, that is, fully customer-operated. ORE. Rev. STat. \$ 714 (1973). Massachusetts specifically allows a bank to have, within the county where the main office is located, unmanned facilities that disburse funds for customer convenience; but no bank may own a share in more than thirteen such facilities. Mass. ANs. LAws ch. 167, $\$ 64$ (1973). Washington's recently enacted statute provides that "satellite facilities" shall not be treated as branches and may be established anywhere within the state. Comptroller's Opinion at 44419 (enacted April 30, 1974). Such state law restrictions on the nature, location, and number of facilities will be binding on national banks' CBCTs, if the terminals are considered branches.

14. Comptroller's Opinion at 44420. The Comptroller went on to say, however, that he would "monitor the development of CBCTs and ... halt or alter their establishment if such action appears appropriate." Id. Just recently, the Comptroller amended his December 12, 1974 ruling to restrict a national bank's CBCTs to locations within filty miles of its headquarters or nearest office or branch, unless the terminals are to be shared with one or more local linancial institutions. See text and notes at notes 114-17 m/ra. This amendment was designed to allay the fears of small banks that larger banks would increase their market share by blanketing the state and exen the country with terminals. Wall St. J., May 12, 1975, at 12, col. 3.

15. Id. at 44419 . 
modern banking practices, ${ }^{16}$ and the competitive position of the national banks vis-à-vis other federally chartered institutions. ${ }^{17}$

This comment explores the question of whether CBCTs fall within the McFadden Act's definition of a "branch." It first considers whether analyzing the McFadden Act's definition of "branch" on its face can resolve the problem of how to apply the provision to CBCTs. Finding this approach inconclusive, the comment then discusses the pertinent legislative history and subsequent case law. Since the courts have increasingly stressed that "competitive equality" between the national and state banking systems is one of the chief guides to interpreting the definition, that doctrine is subjected to a critical evaluation. Finally, the comment draws on the statutory policies to formulate a definitional test and to offer some tentative conclusions about the status of CBCTs under that test.

\section{The Statutory Framework}

In section 36(f) of title 12 of the United States Code-originally part of the McFadden Act-a somewhat circular provision defines the term "branch" to

include any branch bank, branch office, branch agency, additional office, or any branch place of business located in any State or Territory of the United States or in the District of Columbia at which deposits are received, or checks paid, or money lent. ${ }^{18}$

16. Id. The Comptroller's attitude is shared by the Federal Reserve Board (FRB), which anticipates that it eventually will install and manage the backbone of the electronic payments system. See text and note at note 4 supra; 58 FEd. Res. Bull. 1010 (1972). As a step towards that system, the FRB has issued Regulation J, a measure that reduced float in the present system by requiring all banks to pay checks presented to them by the Federal Reserve Banks on the day presented, out of readily available funds. See id. at 626.

17. Comptroller's Opinion at 44419. The Comptroller is particularly apprehensive about competition from federal savings and loan associations. The Federal Home Loan Bank Board (FHLBB) issued a ruling in June 1974 allowing federally chartered savings and loans to establish "remote service units" that can transfer funds, accomplish cash withdrawals, and receive loan payments. 39 Fed. Reg. 23991 (1974). The FHLBB's conclusion that the remote terminals are not branches was not a determinative factor in authorizing their installation, since federal savings and loans are not subject to state branch banking restrictions. 12 C.F.R. $\S 545.14$ (1974). In August 1974 the National Credit Union Administration issued a temporary ruling allowing credit unions to submit pilot programs involving the use of remote terminals. $39 \mathrm{Fed}$. Reg. 30107 (1974).

18. 12 U.S.C. $\$ 36(f)(1970)$. 
It is clear that branching occurs whenever one of the three functions set out in the definition is performed by a bank at a location that can be construed as an "additional office." 19 In applying this statutory definition, CBCTs can be analyzed in terms of the situs of the transaction, the physical characteristics of the terminal, or the functions performed by the terminals. None of these approaches gives an entirely satisfactory answer to the problem at hand.

\section{A. The Situs of the Transaction}

Until the Comptroller's ruling, the CBCT was generally known as an "ATM" or "automated teller machine." But the term "teller" suggests that an independent transaction occurs at the site of the terminal; the Comptroller therefore chose a new name that emphasizes the communications link between the bank and the CBCT. ${ }^{20}$ In the Comptroller's written opinion, the CBCT is compared to a mailbox serving as no more than a conduit; ${ }^{21}$ as far as the bank is concerned, the transaction is consummated at the banking house. ${ }^{22}$ Fixing the situs of the transaction solely by reference to the bank's viewpoint, however, ignores the perspective of the customer, who can complete his own participation in certain banking transactions at the site of the terminal. Since the electronic transaction really has two locations-the bank's computer and the terminal itself-any attempt to fix a single situs must ultimately fail. ${ }^{23}$

19. First Nat'l Bank in Plant City v. Dickinson, 396 U.S. 122 (1969), discussed in text and notes at notes 68-88 infra.

20. This approach is suggested in Kirby, The Name's the Thing: Financial Communication Detice, Not Automated Teller Machine, 91 Banking L.J. 135 (1974). Kirby argues that the terminals are simply mechanical devices that fall "into exactly the same functional category as the United States mails, telegraph, telephone, and other forms of data communication whereby portions of banking transactions are and have for many years been conducted by many individuals." Id. at 142 (emphasis in original).

21. Comptroller's Opinion at 44418.

22. Id. at 44421 .

23. The Attorney General of Kansas has issued an opinion stating that an on-line CBCT is not a branch, because the transaction is performed in the bank's computer. Kan. Att'y Gen. Op. No. 74-196 (June 12, 1974). This opinion was sharply criticized by another Kansas official, Assistant Bank Commissioner Edmond Hogan, who noted that half of the banks in the state did not have computers on their premises, because correspondent banks performed their data processing for them. Therefore, he said, "the opinion is contradictory, since banking transactions transpire in a computer which is not on the premises." American Banker, July 8, 1974, at 1. 


\section{B. Physical Characteristics of the Terminal}

A second way to analyze the CBCT is through its physical attributes. In his opinion accompanying the current ruling, the Comptroller argues that the CBCT cannot be an "additional office" because it does not possess the physical or personnel characteristics of the teller windows of the early 1920s, which were the targets of the "additional office" classification. ${ }^{24}$ This argument is pitched on a basic, common sense level: it is difficult to reconcile the $\mathrm{CBCT}$, which resembles a vending machine, with the traditional image of a banking office. In his dissenting opinion in First $\mathrm{Na}$ tional Bank in Plant City v. Dickinson, ${ }^{25}$ Justice Douglas registered a similar reaction: "[I]t will come as a shock, where common sense is the guide, to learn that an armored car picking up merchants' cash boxes and checks is a branch bank." 26

Opponents of the Comptroller's ruling, however, could argue with equal cogency that these terminals are no more than "teller windows" resurrected in automated form. The McFadden Act is directed at any "form of office" 27 at which the enumerated banking functions are performed, and, although legislators in the 1920 s could not foresee automation, a CBCT shares a number of physical characteristics with facilities that clearly are branches. A CBCT is a permanent facility located apart from the bank's main premises, identified as an extension of the bank, and held out to the public as providing banking services at that location. It can be argued that these similarities are sufficient to justify application of state branch banking laws to the installation of offpremises CBCTs.

\section{Functions Performed by CBCTs}

Perhaps it is most attractive to analyze the CBCTs in terms of the functions they perform. This view assumes that the CBCT would qualify as an "additional office" and inquires whether deposits are received or checks paid at the terminal. ${ }^{28}$ For this analysis

24. Comptroller's Opinion at 44418.

25. 396 U.S. 122 (1969).

26. Id. at 138 (Douglas, J., dissenting).

27. H.R. Rep. No. 583, 68th Cong., 1st Sess. 3 (1924).

28. One might argue that a loan is made off-premises when a cash advance on a credit card is dispensed or when a customer is allowed to overdraw his checking account. But these payments are only the proceeds of "loans" arranged at the bank when the credit or checking account agreement was originally signed. See Comptroller's Opinion at 44421 . As long as the use of bank credit cards to make purchases does not constitute branching, it is difficult to see how a cash advance can be so characterized. 
it becomes necessary to distinguish between CBCTs that are operated by the customer himself and CBCTs that are operated by an employee of a retail store (sometimes called "point-of-sale terminals"). As a rule, the former dispense cash and receive monies directly; the latter transmit information and initiate transfers of funds.

1. Customer-Operated Terminals. In his analysis of customer-operated CBCTs, the Comptroller has taken a highly technical view of the statutory language, construing the words "deposit" and "check" as terms of art. A "deposit" is said to occur only when a contractual debtor-creditor relationship has been created between the bank and its customer; consequently, there can be no "deposit" at the site of a customer-operated terminal, because money and checks placed in the machine cannot be credited to the customer's account until they are received and verified at the main bank. No machine yet developed is capable of reading checks and counting the money deposited in it. ${ }^{29}$ Thus the CBCT is viewed as similar to the mailbox in which a customer places a deposit to be credited to his account when received at the main bank. Similarly, a "check" in the Comptroller's analysis is a written instrument signed by the drawer. ${ }^{30}$ With the customer-operated terminal, there is no written instrument; instead the customer inserts his identification card and pushes a set of buttons to select the amount of cash he wishes to withdraw.

Of course, one could construe the language of the statute much more broadly, ignoring the intricacies of the transaction while concentrating on the result. The CBCT allows the bank customer to make his deposit in a secure receptacle or to receive cash at a site far removed from the main bank building. Because these operations are the functional equivalents of depositing and check cashing from the customer's point of view, it can be argued that the off-premises facilities should be considered branching. As one district judge remarked in a case involving a drive-in teller facility, " 'branchness' is a combination of function and physicality 一not bookkeeping."31

The difference between goods received on credit and a cash advance is not great enough to justify different treatment of the two transactions. Holders of some bank credit cards can presently obtain cash advances from any bank cooperating in their credit card system.

29. Comptroller's Opinion at 44421.

30. Accord, Uniform Commercial Code § 3-104; see Comptroller's Opinion at 44421.

31. State Chartered Banks in Wash. v. Peoples Nat'l Bank, 291 F. Supp. 180, 195 (W.D. Wash. 1966). 
2. Terminals Operated by Retail Store Employees. With a customeroperated terminal, the bank customer draws directly from, or deposits directly into, his account; with the store-operated terminal, on the other hand, the store's account with the same bank is used as an intermediary. To handle a deposit, the store retains the customer's money or check and an electronic transfer of funds is accomplished, with the store's account being debited and the customer's account being credited for the designated amount. A withdrawal of cash entails some variation on the reverse process. In one scheme, the customer makes out his check to the store and the store gives him the cash, using the CBCT to determine whether the customer has sufficient funds on deposit to cover the check. In this situation it is likely that the bank will guarantee payment of every check approved through the CBCT, putting a "hold" on the customer's account for the amount of the check. Alternatively, there can be a complete transfer of funds, with the CBCT initiating a debit to the customer's account and a simultaneous credit to the store's account. ${ }^{32}$

With the store-operated terminal the controversy is not whether a deposit is received or a check paid off-premises, but rather whether the retail store is acting as an agent of the bank. Because a store employee verifies the customer's deposit and, in effect, orders a credit to the customer's account, it is clear that, even under the Comptroller's standard, a deposit is "received" at the off-premises location. But, the Comptroller argues, it is the store, not the bank, that receives the deposit and (where a written instrument is involved) pays the check. ${ }^{33}$ According to the Comptroller, the store does not act as an agent for the bank in performing these services, because it has a bona fide business purpose of its own. ${ }^{34}$ Moreover, it would seem that the store must assume certain risks in the transaction. It would be most logical to allocate risks in accordance with the ability of each party to control different aspects of the situation: the store should be responsible for identifying the customer accurately and for initiating the transaction in a proper manner; ${ }^{35}$ the bank should be responsible only for errors made by the system itself.

Opponents of the CBCTs could argue, on the other hand, that the store cannot be anything but an agent for the bank, since the

32. Comptroller's Opinion at 44422 .

33. Id.

34. Id.

35. Presumably, the store must at least bear the risk that any cash given to it in return for "crediting a customer's account might be stolen while still in the store. 
bank completely controls every transaction through the machine. In the conventional check-cashing operation at a retail store, the store has a great deal of discretion in deciding whether or not a particular customer will be allowed to cash a check. Where a CBCT is used, on the other hand, the bank chooses whether a check is to be cashed, relaying its decision through the terminal. ${ }^{36}$ The store is simply a conduit for the transaction.

Equally inconclusive is another variation on the functional approach-one that might be invoked to show that store-operated CBCTs are not branches when used for purposes other than receiving deposits, cashing checks, or lending money. Store-operated CBCTs need not be confined to pure banking functions. They can also be used to obtain authorization for credit card sales, to inquire whether or not a customer has sufficient funds to cover a check, to guarantee that check by placing a "hold" on the customer's account, and to consummate purchases by transferring funds directly from the customer's to the store's account. ${ }^{37}$ When used for these purposes, the CBCT can be regarded as simply a device to automate and improve existing procedures that clearly do not constitute branching. Thus, instead of telephoning the bank to check the status of a customer's account, the store employee presses a few buttons on the terminal's console. Instead of being physically transported to the bank and sent through a long collection process, the electronic "check" is presented and paid instantaneously. It can be argued that since these CBCT transactions do not fall within the explicit functional terms of the statute, such use of the terminal is not branching.

But there are difficulties with using the functional approach to exclude facilities from the McFadden Act definition. That definition says that offices which receive deposits, pay checks, or lend money are "include[d]" within the meaning of the term "branch"; 38 on its face the definition does not necessarily exhaust the pos-

36. Similar analysis was used by the Attorney General of Illinois in holding that the state's definition of "branch" included a type of currency dispensing machine that was to be placed in two banking houses. Under this plan, the customers of either bank could have withdrawn cash and received credit card advances from the machine located in the other bank. The Attorney General said that ordinarily, when cashing a check drawn on another institution, a bank simply acts as agent for the bearer of the check. But when a machine is introduced, the bank loses its discretion to refuse to pay the cardholder; thus it becomes an agent of the drawee bank. ILL. ATr'y GEN. Op. No. S-734 (1974).

37. In his opinion, the Comptroller explicitly put to one side the authorization and check guarantee functions of a CBCT, finding that they were already permissible uses of remote terminals. Comptroller's Opinion at 44417.

38. 12 U.S.C. $\$ 36(f)(1970)$. 
sible kinds of facilities that may be "branches."39 Thus, it could be argued that any bank-owned off-premises facility at or through which significant banking transactions are accomplished constitutes a branch. Under this view the bank-owned CBCT that transfers information and funds could fall within the "branch" category.

As the above discussion demonstrates, the question of when a CBCT is a branch, if ever, cannot be resolved by an examination of the statute alone. It is therefore necessary to rely on the legislative policy underlying the McFadden Act, as it emerges from the legislative history and from subsequent cases applying the Act.

\section{The Legislative History}

The National Bank Act of $1864^{40}$ did not mention branches, ${ }^{41}$ but in 1923-after several states had allowed their chartered banks to branch-the Attorney General of the United States ruled that the incidental powers of national banks included a power to establish "teller windows," remote from the banks' main offices, for the purposes of receiving deposits and paying checks. ${ }^{42}$ The Supreme Court overturned this ruling in First National Bank of St. Louis v. Missouri ex rel. Barrett," ${ }^{43}$ concluding that "the mere multiplication of places where the powers of a national bank may be exercised is not ... a necessary incident of a banking business." 44 To the Attorney General's argument that the power to establish teller windows had become "necessary" because of competition with branch offices of state banks, the Court replied that Congress alone could remedy the situation. ${ }^{45}$

A month later, Representative McFadden introduced a bill to allow national banks to branch within their own cities if state banks were allowed to do so by state law. ${ }^{46}$ Throughout the debates, the

39. First Nat'l Bank in Plant City v. Dickinson, 396 U.S. 122, 135 (1969).

40. Act of June 3, 1864, ch. 106, 13 Stat. 101 (codified in scattered sections of 12 U.S.C.).

41. The omission was possibly due to the relative scarcity of branch banks at the time the Act was passed. First Nat'l Bank in Logan v. Walker Bank \& Trust Co., 385 U.S. 252, 257 (1966).

42. 34 Op. Atr'y Gen. 1, 5 (1923). The legal basis for his opinion was the National Bank Act of 1864, ch. 106, § 8, Seventh, 13 Stat. 101, as amended, 12 U.S.C. § 24, Seventh (1970), which permits national banks to "exercise . . . all such incidental powers as may be necessary to carry on the business of banking."

43. 263 U.S. 640 (1924).

44. Id. at 659 .

45. Id.

46. The bill originally introduced was H.R. 8887, 68th Cong., 1st Sess. (1924). After it failed to pass in the Senate, the House managers reintroduced it as H.R. 2, 69th Cong., 1st Sess. (1926). 
sponsors of the bill maintained their opposition in principle to branch banking, ${ }^{47}$ but insisted that the proposed measure was vital to the survival of the national banks and the Federal Reserve System. Representative McFadden described the accelerating trend towards conversion of national banks into state chartered institutions; he argued that eventually, if the trend persisted, the Federal Reserve would be left with only voluntary-that is, state bank - members and that the stability of national monetary policy would therefore be seriously undermined. ${ }^{48}$

To meet arguments made by opponents of branch banking, ${ }^{49}$ proponents of the measure emphasized the limited branching power authorized by the bill. They pointed to a provision confining state banks to citywide branching if they were members of the Federal Reserve System. ${ }^{50}$ Although they agreed that statewide branching led to monopoly and absentee credit control, ${ }^{51}$ they found citywide branching more defensible, especially since it amounted to a "service proposition."52 In their view, crowded conditions in large metropolitan areas had made the need for convenient banking facilities acute: "economy in time, energy and many other factors demand that the old order give way to a more sensible and modern form." 53

47. Representative McFadden was fond of characterizing the measure as more "anti" than "pro" branch banking. 66 CoNG. REc. 1582 (1925). According to McFadden, everyone agreed that the welfare and stability of the country depended on the continued integrity of the unit banking system, especially in small towns and rural areas. Id.

48. 65 Cong. Rec. 11296-97 (1924). See also H.R. Rep. No. 583, 68th Cong., 1st Sess. 1 (1924): "The national banking system is facing an emergency which affects its very existence and ultimately the existence of the Federal reserve system. This situation is due to the fact that the national banks, operating under the law of 1864 with amendments, lack the necessary charter powers to give the most complete modern banking service."

49. Representative Goldsborough stated flatly that if the bill passed there would certainly be a total destruction of unit banking in the United States within ten years. 66 Cong. Rec. 1624 (1925); cf. id. at 924 (1925) (remarks of Representative Frear) (bill is "the camel's nose under the tent"). The American Bankers' Association stated that "[b]ranch banking is contrary to public policy, violates the basic principles of our Government, and concentrates the credit of the Nation and the power of money in the hands of a few." 66 Cong. Rec. 1575 (1925).

50. Act of Feb. 25, 1927, ch. 191, §9, 44 Stat. 1229, amending section 9 of the Federal Reserve Act.

51. See 65 Cong. Rec. 11297 (1924) where Representative McFadden characterized statewide branching as an "unsound and un-American form of banking" leading to absentee control of a community's finances.

52. See 66 Cong. REc. 1645, 1767 (1925) (remarks of Representative McFadden).

53. 66 Cong. Rec. 1775 (1925) (remarks of Representative Watkins). 
The McFadden Act's definition of a "branch"54 emerged in the context of this balancing of the merits and risks of branching. Some Congressmen were outraged that even three members of the Supreme Court had dissented in the Barrett case; they feared that the Court might someday overrule Barrett, thus allowing national banks to set up teller windows as one of their "incidental powers." The Congressmen were concerned that these teller windows, which often had been large structures manned by a substantial complement of bank personnel, ${ }^{55}$ might capture favorable locations and compete on nearly equal terms with neighboring unit banks. ${ }^{56}$ Representative Stevenson responded to these fears by stating that the possibility of unrestricted use of teller windows had been "cut ... out, root and branch" by the McFadden bill's definition. Instead, he maintained, state law would govern teller windows in the same way that it would affect other branches. ${ }^{57}$

In the general reexamination of banking policy that took place during the Depression, branch banking was once again an object of scrutiny. The failure of many small, undercapitalized rural banks convinced some former Congressional opponents of branching that the only protection against widespread bank failures was a branch banking system. Senator Glass, one of the converts, ${ }^{58}$ introduced a bill to allow statewide branching by national banks without regard to state law. ${ }^{59}$ As finally enacted, however, the Glass-Steagall Act of $1933^{60}$ authorized statewide branching by both national and state member banks, but only to the extent "authorized to State banks by the statute law of the State in question by language specifically granting such authority affirmatively and not merely by implication or recognition." 61

In effect, Congress-internally divided about the value of branch banking-had placed on state legislatures the responsibility of deciding whether branching was sound public policy for their respective states. The rationale for this delegation was not that the states should decide every issue that affects the relative competitive positions of state and national banks. Instead, the states

54. The definition appears in the text at note 18 supra.

55. 67 CoNG. REc. 2860 (1926) (remarks of Representative Celler).

56. Id.

57. 66 Cong. ReC. 1627 (1925).

58. See 75 Cong. Rec. 9890 (1932).

59. S. 4412, 72d Cong., Ist Sess. (1932).

60. Act of June 16,1933 , ch. 89,48 Stat. 162.

61. Id. $\S 23(\mathrm{c})(2)$ (codified at 12 U.S.C. $\$ 36(\mathrm{c})(2)(1970)$ ). For a discussion of the statute's requirement that branching be expressly authorized, see note 95 infra. 
were to be allowed to make their own choices in the realm of branching-weighing the benefits of convenience against the threat of monopolization. ${ }^{62}$ Congress consciously made the accompanying "branch" definition broad enough to include facilities, such as teller windows, that presented the same mix of policy questions conventional branches did. But Congress had no immediate need to further define the limits of "branching," because it could not foresee the technological developments of the future. The courts were thus left with little to work from by way of legislative history.

\section{Judicial INTERPRETAtions OF THE Legislative History}

\section{A. The Walker Bank Decision}

One issue that the case law has decisively resolved is the extent to which state policy governs the manner in which branch offices, when identified as such, may be established by national banks. In the leading case, First National Bank of Logan v. Walker Bank E Trust Co. ${ }^{63}$ the Supreme Court unanimously held that the Comptroller was required to follow a Utah statute that permitted establishment of a branch only by acquisition of an existing bank that had been in operation for five years or more. The Comptroller had argued that once a state authorized any branching, federal standards determined the criteria for allowing national banks to open branches in that state. The Court found this argument untenable in light of the policies of the McFadden and GlassSteagall Acts. In assessing the pertinent legislative history, ${ }^{64}$ Justice Clark's opinion for the Court recognized that the "intent of Congress [was] to leave the question of the desirability of branch banking up to the States." 65 This intent was to be implemented

62. See Comment, Federalism in Interpretation of Branch Banking Legislation, 32 U. CHI.

L. REv. 148, 160 (1964) [hereinafter cited as Chicago Comment].

63. 385 U.S. 252 (1966).

64. See id. at 257-60. The following two quotations are illustrative:

The Senate Report [on the McFadden bill] concluded that the Act should permit "national banks to have branches in those cities where State banks are allowed to have them under State laws."

Id. at 258, quoting S. Rep. No. 473, 69th Cong., 1st Sess. 14 (1926).

"In the controversy over the respective merits of what are known as 'unit banking' and 'branch banking systems,' a controversy that has been alive and sharp for years, branch banking has been steadily gaining in favor. It is not, however, here proposed to give the advocates of branch banking any advantage. We do not go an inch beyond saying that the two ideas shall compete on equal terms and only where the States make the competition possible by letting their own institutions have branches."

385 U.S. at 260, quoting 77 CoNG. REC. 5896 (1933) (remarks of Representative Luce).

65. 385 U.S. at 258. 
through a policy of " 'competitive equality' insofar as branch banking was concerned." 66 Thus, under the Walker Bank theory, state and national banks compete on an individual basis, but neither system has branching privileges unavailable to the other. The Comptroller must apply the state statutory provisions in their entirety when he is considering a national bank's branch application; although not bound by state judicial or administrative interpretations, ${ }^{67}$ the Comptroller is to act on each application by interpreting the state statute itself, as if he were the state superintendent of banks.

Because the facility involved in the Walker Bank case was clearly a branch, the Court did not consider what other facilities would constitute a "branch" and thus be subject to the policy of "competitive equality." In the 1960s, however, the introduction of new types of convenience banking facilities-principally drive-in teller windows, armored car messenger services, and deposit machines -brought that issue to the attention of the judiciary. Justice Clark's stress on equality between the state and federal systems foreshadowed and to some extent influenced the path that the courts would take.

\section{B. The Plant City Decision}

The Supreme Court's decision in First National Bank in Plant City v. Dickinson ${ }^{68}$ warrants close scrutiny, both because it has been widely followed ${ }^{69}$ and because its factual context is quite similar to that surrounding CBCTs. In 1966, the Comptroller issued interpretive rulings ${ }^{70}$ authorizing national banks to operate mobile messenger services and off-premises deposit machines as exercises of their incidental powers, without regard to state branch banking restrictions. Although sums intended for deposit would be received at these facilities, ${ }^{71}$ the Comptroller concluded that branching would not occur so long as a bank's contracts of deposit specified that monies would not be deemed deposited until they had been brought to the tellers at the main bank. Under this view, the armored car messengers would act as agents of the customers

66. Id. at 261 .

67. See text and note at note 96 infra.

68. 396 U.S. 122 (1969).

69. See, e.g., text and notes at notes 89-91 infra.

70. 12 C.F.R. $\$ 7.7490$ (1966) (mobile messenger service); id. $\S 7.7491$ (deposit machines).

71. In practice, the armored cars also performed certain check cashing functions; the Plant City litigation, however, focused on the deposit function. 
in delivering the deposits to the bank-even though the messengers were bank employees. With the deposit machine, the completion of the transaction would depend on the verification and crediting of deposits at the main banking house.

Pursuant to the Comptroller's authorization, the First National Bank in Plant City, Florida-a state that prohibits branchingestablished an armored car messenger service and a stationary receptacle for deposits. State banking officials protested and the bank sued in federal district court for declaratory and injunctive relief. The district court upheld the Comptroller's ruling and the bank's use of the facilities, ${ }^{72}$ finding that the federal definition of a "branch" was exclusive: if there were no deposits received, or checks paid, or money lent at an off-premises facility, then it could not be considered a branch. ${ }^{73}$ The state statute prohibiting branches could not bind national banks, the judge said-even if it were interpreted by state officials to prohibit use of the same type of facility by state banks. ${ }^{74}$ Under the district court's interpretation of the federal definition, to have said that deposits were received or checks paid at the mobile facility or the deposit receptacle would have been to ignore the clear effect of the deposit and agency contracts. ${ }^{75}$ This the court refused to do, holding that the existence of a dual agency-on behalf of both the bank and the customer-did not vary the effect of those contracts. ${ }^{76}$

The Fifth Circuit reversed this decision, ${ }^{77}$ holding that the mobile messenger service and the deposit receptacles were "branches"; the contracts of deposit were found insufficient to shield them from this designation, since the Florida Comptroller had construed the facilities to be branches under Florida law. Citing Walker Bank's doctrine of "competitive equality," the panel stated that they "must not look to Section 36(f) [of the McFadden Act] as their sole guiding light but must permit rays of state law to refract and reflect their statutory vision." 78 At one point in its opinion, the Fifth Circuit concluded that the federal definition is a partial, functional way of describing a branch; under this view, the court should determine whether state law adds any further refinements. ${ }^{79}$ This

72. First Nat'l Bank in Plant Gity v. Dickinson, 274 F. Supp. 449 (N.D. Fla. 1967).

73. Id. at 454 .

74. Id.

75. Id.

76. Id.

77. Dickinson v. First Nat'l Bank in Plant City, 400 F.2d 548 (5th Cir. 1968).

78. Id. at 554 .

79. Id. at 555 . 
approach, as opposed to a "federal common law of branching," was seen as providing the flexibility necessary to accomplish the goals set out in the McFadden Act. At a later point in its discussion of the relationship between federal and state definitions of a "branch," the court went even further and concluded that state law definitions and their interpretations by state bank supervisors and courts would control the definition of a "branch" for national banks as well. ${ }^{80}$

In the Supreme Court, the Government argued that the district court interpretation had been the correct one. It pointed out that the competitive equality concept applied only to the manner in which branching was accomplished and could not logically be injected into the threshold definitional question of whether a particular installation was a branch. The brief stated that the result of following the Fifth Circuit's reliance on the Florida definition would be to allow the states "to confine the service activities of national banks to the banks' four walls if the state so chooses." 81 It went on to list activities of national banks regularly performed off-premises that could be curtailed under this interpretation: "new-business solicitation, loan closings, sale of money orders and travellers' checks, banking by mail, credit card services, various correspondent services, and data processing." 82 In response, Florida Comptroller Dickinson argued that many of these activities would not be covered by the branch definition, because they did not involve the construction of an additional permanent place of business. Moreover, he argued, state supervisors would not unduly restrict national banks, because any such policy would be unacceptable for state banks as well. The policies of the McFadden Act demanded state input into the federal definition: "clearly competitive equality cannot exist in the branching area if, in any given state, state and national banks are governed by separate and inconsistent definitions of branching." ${ }^{33}$ In the absence of an explicit federal law permitting a particular off-premises activity, the state comptroller argued, the state prohibition should control.

The Supreme Court affirmed the Fifth Circuit's judgment, ${ }^{84}$ holding that deposits had been received off-premises in violation of federal branch banking restrictions. Chief Justice Burger, writ-

80. Id. at 557-58.

81. Petitioner's Brief for Certiorari at 11 .

82. Id. at 12.

83. Brief for Respondent at 7.

84. 396 U.S. 122 (1969). 
ing his first full-length opinion for the Court, dismissed the contracts of deposit as transparent fictions designed to circumvent the branch banking laws in a "systematic attempt" to secure for national banks branching privileges denied to state banks. He indicated that private contracts, while perhaps appropriate for allocating the risks of a banking enterprise, could have no significance in a determination of whether or not that enterprise involved branching.

The Court found that the definition of "branch" was a matter of federal law. To allow state law definitions to control, it said, would allow the states to be "the sole judges of their own powers," a result Congress clearly had sought to avoid by including a definition. ${ }^{85}$ Although the .Court thus rejected the Fifth Circuit's interpretation as overbroad, it did not restrict the definition of a branch to the three functions set out in the statute:

Although the definition may not be a model of precision, in part due to its circular aspect, it defines the minimum content of the term "branch"; by use of the word "include" the definition suggests a calculated indefiniteness with respect to the outer limits of the term. However, the term "branch bank" at the very least includes any place for receiving deposits or paying checks or lending money apart from the chartered premises; it may include more. ${ }^{86}$

Left with this ambiguous definition, Chief Justice Burger returned to what he saw as the keystone of the McFadden Act as interpreted by Walker Bank: competitive equality. Since the mobile messenger service and the deposit receptacles were "part of a large-scale continuing mode of conducting the banking business designed to bring basic banking services to customers," they "[u]nquestionably" gave an edge to national banks over state banks. ${ }^{87}$ Such an advantage seemed to show that the Comptroller had been unreasonable in ruling that the armored cars and deposit receptacles were not branches. ${ }^{88}$

85. IH. at 133-34.

86. Id. at 135 (emphasis in original).

87. Id. at 137.

88. Justices Douglas and Stewart objected to this interpretation in their dissenting opinions. They would have allowed the Comptroller to construe the term "deposit" in its narrowest sense, as the initiation of a contractual debtor-creditor relationship. Both stressed that the Comptroller, being responsible for administering the National Bank Act, was entitled to deference in his construction of that Act. Id. at 140, 141. See note 119 infia. 
As construed in Plant City, the federal definition of "branch" in section $36(f)$ appears to be exceedingly broad. A national bank has no incentive to set up off-premises customer facilities unless they are likely to help the bank attract or hold the public's business. Thus one would always expect to find that a national bank using them enjoys some competitive advantage over state banks forbidden to do so. The Plant City opinion did not indicate that any particular amount of competitive disadvantage to state institutions was necessary before a facility would become a "branch"; apparently any inequality will be sufficient to bring the branching prohibition into play.

\section{The Drive-In Cases}

Plant City has already influenced the outcome of one line of cases that has approached the McFadden Act definition of "branch" from a different direction. In the mid-1960s, before their states passed laws specifically allowing drive-in teller windows, some national banks sought authority from the Comptroller to build such facilities in close proximity to their main bank buildings. The Comptroller typically replied that, although formal certification was necessary to establish a branch, no permission was required to expand an existing facility. As he told one bank, if the "locations, because of their proximity, [would] constitute but one operation in the public mind," the drive-in facility would be considered an extension of the main building. ${ }^{89}$

But in subsequent litigation the courts have applied a broader standard in considering whether a given drive-in facility was a branch. As the Comptroller's analysis suggested, they have taken into account the distance from the main bank to the drive-in window. But they have also investigated the possibility that a national bank using the facility might enjoy a competitive advantage over state banks in the area. Thus, where similar facilities had been authorized for state banks when the state supreme court adopted the Comptroller's "unity of operations" theory, the drive-in facility at a national bank was not considered a branch. ${ }^{90}$ On the other hand, where state law allowed state banks to have only one drive-

89. Driscoll v. Northern Nat'l Bank of St. Paul, 484 F.2d 173, 176 (8th Cir. 1973); cf. Dunn v. First Nat'l Bank of Carterville, 345 F. Supp. 853 (N.D. Ga. 1972) (informal approval of contiguous installment loan building as extension of main facility).

90. North Davis Bank v. First Nat'l Bank of Layton, 457 F.2d 820 (10th Gir. 1972); cf. Dunn v. First Nat'l Bank of Cartersville, 345 F. Supp. 853 (N.D. Ga. 1972). See also Virginia ex rel. State Corp. Comm'n v. Farmers \& Merchants Nat'l Bank, 380 F. Supp. 568 (W.D. Va. 1974). 
in facility and a national bank sought to build its second drive-in facility, the "unity of operation" theory was rejected and "branching" was found.91 "Competitive equality," then, is increasingly identified as the key to interpreting section $36(\mathrm{f})$, and an evaluation of the validity of that approach is very much in order.

\section{A Critique of "Competitive Equality"}

Walker Bank marshalled a convincing array of legislative history to show Congress's intention that, where national banks established branches, they would have to meet the requirements imposed by state law and thus stand in a position of "competitive equality" with state banks. The Plant City Court relied upon the identical sources $^{92}$ to attribute a quite different purpose to Congress: that "competitive equality" between the national and state banking systems should be relevant to the definition of a branch. A careful reading of the passages quoted in the two opinions ${ }^{93}$ indicates that the Congressmen were saying only that national bank branches must compete on equal terms with state branches; the quotations do not deal with the definitional problem at all.

The Plant City Court appears not to have thought out the problem of how the statute should be construed to promote "competitive equality." In fact, is is difficult to discern the interpretive technique the Court favored.

Under one possible interpretation of the Court's reasoning, there is a single definition of "branch" applicable nationwide; once a determination has been made that a particular type of facility is a branch, its use by any national bank would be subject to state restrictions on branch banking. Actual competitive equality, however, cannot be achieved under this interpretation. The reason is that section 36(c) allows national banks to establish branches in their cities only if such branches are "expressly authorized" by state law; ${ }^{94}$ national banks can establish branch banks in

91. See Driscoll v. Northwestern Nat'l Bank of St. Paul, 484 F.2d 173 (8th Cir. 1973). See also Jackson v. First Nat'l Bank of Valdosta, 246 F. Supp. 134 (M.D. Ga. 1965) (decided before Plant City).

92. All of the quotations Plant City used to demonstrate the "competitive equality" policy had also appeared in Walker Bank.

93. See note 64 supra.

94. 12 U.S.C. $\$ 36(c)(1)(1970)$ (emphasis added). These words were added by the Glass-Steagall Act. Act of June 16, 1933, ch. 89, $\$ 23(c)(1), 48$ Stat. 189. There is evidence that Representative McFadden may have regarded the earlier legislation as carrying the same meaning, see 68 ConG. REC. 5815 (1927), but the provision as then enacted allowed citywide branching whenever "permitted ... by the law of the State in question." Act of Feb. 25, 1927, ch. 191, § 7, 44 Stat. 1228. 
other parts of a state only if state banks are authorized to do so "by the statute law of the state in question by language specifically granted such authority affirmatively and not merely by implication or recognition."95 These provisions have been held to require federal courts to look only to the face of the statute, disregarding state judicial and administrative interpretations. ${ }^{96}$ Thus, when a state statute is interpreted as impliedly authorizing state banks to use a particular off-premises facility-hardly a frivolous possibility in the case of $\mathrm{CBCTs}^{97}$ - national banks cannot take advantage of that construction to escape the limitations of section 36(c). If the facility is held to be a branch under Plant City, competitive inequality must result. ${ }^{98}$

This result would be particularly troublesome in light of Congress's reasons for making national bank branching subject to state

95. 12 U.S.C. $\$ 36(c)(2)$ (1970) (emphasis added). For the legislative history of this wording see 37 OP. ATr'y GEN. 325 (1933), quoted in pertinent part in Rushton ex rel. Comm'r of Banking Dep't v. Michigan Nat'l Bank, 298 Mich. 417, 427-30, 299 N.W. 129, 133-34 (1941). The language appears to have been added because of an objection by Senator Wheeler, who while offering an equivalent amendment said:

In the State of Montana and in a number of other States there is no law expressly either prohibiting or permitting State branch banking; but the State bank examiner has held that there is nothing in the charter of the State banks permitting [sic; prohibiting?] a branch bank. Under that construction, in my humble opinion, branch banks could be established in that State unless they were expressly prohibited by the law of the State. Consequently, I wanted a provision to be placed in the statute that branch banks shall not be permitted in a State unless the legislature or the people themselves, through an initiative, actually by law say that they shall be permitted there.

76 Cong. Rec. 1997 (1933); see 37 Op. Atr'y Gen. at 327-28.

96. See Howell v. Citizens First Nat'l Bank of Ridgewood, 385 F.2d 528 (3d Cir. 1967), holding that the district court should not have abstained in anticipation of an authoritative state court interpretation of the state branching statute, because the issue was not the state courts' reading, but rather whether the statute affirmatively and on its face authorized the branching in question. The court added that it was uncertain why this "restrictive, mechanical rule for determining the applicability of state branch banking statutes to national banks" was adopted. Id. at 530. But cf. note 95 supra for one explanation. See also First Nat'l Bank of Fairbanks v. Camp, 465 F.2d 586 (D.C. Cir. 1972), holding that when a state supervisor decided that a certain area must remain closed to all future branching, his ruling could not control national banks; to hold otherwise, the court said, would give state supervisors a veto power over operations of national banks. But of: First Nat'l Bank in Mena v. Nowlin, 509 F.2d 872 (8th Cir. 1975) (National Bank Act incorporates state case law on usury limits).

97. Cf. Independent Bankers of Oregon v. Camp, 357 F. Supp. 1352 (D. Ore. 1973). In Texas, Kansas, and Florida, the legality of using CBCTs under some circumstances has been established through opinions of the state attorney general. In Nebraska a state court apparently has held that CBCTs are not branches. See Comptroller's Opinion at 44419 .

98. If, on the other hand, the facility is held not to be a branch under federal law, national banks will have an advantage in states that prohibit use of the facility by their own state banks. Again, competitive inequality is the result. 
restrictions. Representative McFadden offered his bill to make Federal Reserve status more attractive and thus to give national banks an incentive not to convert to state charters. ${ }^{99}$ This legislative policy can hardly justify a construction of section 36 (c) that restricts the powers of national banks compared to those exercised by state banks in the same state.

Under a second possible interpretation of Plant City, a facility could be a "branch" under the McFadden Act in one state but not in another. The federal courts would decide, for each individual state, whether competitive inequality would exist if national banks were entitled to use the facility in question. A finding of inequality under the circumstances would require holding that the facility was a "branch"; if the court found no threat of inequality-for example, if state banks were themselves entitled to use the facility-it would hold that the facility was not a "branch" so far as that state was concerned.

This interpretation of Plant City is also not free from difficulty. Any off-premises customer-related activity by a national bank would give it a competitive advantage over state banks prohibited from engaging in that activity; as a result, under a pure competitive equality standard national banks would always be prohibited from pursuing that off-premises activity. Reading a competitive equality policy into the federal definition would therefore in practice allow the state restrictions to determine the boundaries of that definition. Such a result would be contrary to the Court's conclusion that the definitional issue is, and must be, a federal question.

Since the injection of "competitive equality" into the definitional question was supported by neither historical evidence nor a rigorous analysis of the standard's feasibility, one must wonder why the principle of competitive equality appeared so attractive to the Court. Notwithstanding Walker Bank, there is no reason to believe that Congress regards equality between the federal and state banking systems as important in itself: the federal banking statutes do not mandate absolute equality. National banks have been upheld in their exercise of expressly granted powers ${ }^{100}$ and even implied

99. See text and notes at notes $46-48$ supra. A number of other federal statutes expanding the powers of national banks can also be attibuted to Congress's desire to strengthen the national banking system. See Lewis v. Fidelity \& Deposit Co., 292 U.S. 559, 564-65 nn. 2-7 (1934).

100. See Missouri ex rel. Burnes Nat'l Bank v. Duncan, 265 U.S. 17 (1924), where a national bank's power to act as executor of an estate was upheld despite a state statute prohibiting state banks from acting in that capacity. 
powers ${ }^{101}$ that competing state banks did not possess. ${ }^{102}$ As one commentator has said, "the system of dual banking has not collapsed in the face of such differences, and indeed a 'dual' system has little meaning if the rules in each must always be the same." 103

The Plant City Court seemed to make "competitive equality" between the federal and state banking systems the primary criterion for determining branch status, an emphasis that in light of legislative history and general banking policy was certainly misplaced. The Court could have reached the same result under a sounder and more narrow conception of "competitive equality" - one delimited by the precise sphere of issues that Congress intended to let the states resolve. The next section attempts to formulate such a definition.

\section{A New Definitional Test}

Since the 1920s there has been intense controversy over which banking structure-unit or branch banking-is the more advantageous. Proponents of unit banking argue that branching leads to monopolization, an impairment of credit opportunities for small businessmen, and irresponsible management. ${ }^{104}$ Proponents of branching, on the other hand, argue that it provides a more competitive banking market, broader credit opportunities (because borrowers can draw on larger credit resources), and more efficient management (because of scale economies). ${ }^{105}$ Whatever the merits

101. In Franklin Square Nat'l Bank v. New York, 347 U.S. 373 (1954), the Court held that a national bank's "incidental power" to advertise for deposits could not be precluded by a state statute prohibiting commercial banks from using the word "savings" in their advertising. In each of two other incidental powers cases, Arnold Tours, Inc. v. Camp, 472 F.2d 427 (Ist Cir. 1972), and Saxon v. Georgia Ass'n of Indep. Ins. Agents, 399 F.2d 1010 (5th Cir. 1968), the court, in determining that certain activities were not within the incidental powers of a national bank, never even considered the positions taken by the states on the same question.

102. Conversely, federal law sometimes gives national banks narrower powers than those granted to state banks under state law. Cf. Commissioner v. Morris Trust, 367 F.2d 794 (4th Cir. 1966), in which a state bank merging into a national bank was compelled to "spin off" its insurance business. Under North Carolina law state banks were allowed to be insurance agents, whereas national banks may act as agents only in towns with a population of less than 5000. See id.

103. Chicago Comment, supra note 62, at 163; see Comptroller's Opinion at 44419-20.

104. The arguments have remained remarkably constant over the years. Compare Branch Banking as Viewed by a Country Banker, 71 CoNG. Rec. 5011 (1929) with Hearings on Conflict of State $\mathcal{E}$ Federal Banking Laws of the House Comm. on Banking and Currency, 88th Cong., 1st Sess., ser. 1, pt. 3, at 26 (1963) (statement of Dr. Robert Lanzillotti, Chairman, Department of Economics, Michigan State University) [hereinafter cited as Hearings on Conflict of Laus].

105. Compare 76 Cosc. Rec. 168 (1932) (article from N.Y. Times inserted by Senator Thomas) with Horvitz \& Schull, Branch Banking, Independent Banks, and Geographic Price Discrimination, 14 ANTITRUST BuLL. 827 (1969). 
of these arguments, Congress chose, in the McFadden and GlassSteagall Acts, to remove itself from the debate. All states are entitled to adopt either theory, and national banks must abide by their respective choices. In deciding whether the CBCT, or any other off-premises facility, constitutes a branch, it is appropriate to examine in detail the rationale for the limitation or prohibition of branches, and then to ask whether similar considerations would call for a proscription on the use of the facility in question.

\section{A. A Definitional Test Based on the Rationale for Prohibiting Branches}

Opponents of branching argue that a fully developed branch banking system will tend to concentrate resources in the hands of a few banks. This concentration is said to lead to a decrease in general economic activity-as alternative sources of credit dry up, the price of credit rises, and new enterprises are unable to obtain necessary financing. The independent unit bank, according to this view, is willing to grant loans on the basis of "character" rather than "collateral." Because all their resources and their management personnel come from the community, the unit banks supposedly have a keen sense of local credit needs. Branch banks, however, are seen as outsiders. Both their resources and their control are believed to come from a parent bank far removed from the local situation. Critics of branch banking see in the large branch systems an "affinity" for other large concentrations of capital; opponents thus argue that branch banks ignore the small businessman in order to be able to give credit to large corporations. Moreover, the critics say, when the small businessman is denied a loan at a branch, the whole system is closed to him. And if the market includes nothing but a few branch systems, his chances of receiving credit at all will be very slim. ${ }^{106}$

Unit banking proponents cite two ways in which undue concentration of resources occurs once branching is introduced. First, branches pre-empt the establishment of new unit banks by moving into an area that is not yet capable of supporting an independent bank; then they simply hang on, with the resources of the parent behind them, until the situation improves. ${ }^{107}$ Second, branches are said to drive out existing unit banks by temporarily cutting the

106. This analysis is taken from the statement of Dr. Lanzillotti, Hearings on Conflict of Laus, supra note 104, at 26.

107. Id. at 28. 
price of credit or by simply providing the public with more convenient banking locations. ${ }^{108}$

Assuming that all of the foregoing arguments against branching are valid, ${ }^{109}$ the appropriate question to ask about any given offpremises facility is whether it could lead to an increased concentration of resources in the same way that a more traditional branch does. Thus, the issues are whether the facility could pre-empt favorable banking locations and whether its operations could create a significant competitive advantage for larger banks over smaller institutions. This type of competitive advantage differs fundamentally from the advantage the Plant City Court found to affront the concept of competitive equality. Where competitive equality in the Plant City sense is involved, the comparison is between one bank allowed by law to engage in a particular activity and a second bank forbidden by law to do so. Where the problem is concentration of resources, one assumes that all banks are permitted by law to engage in the activity; the question is whether the stronger economic position of some banks will become further entrenched when they do so.

\section{B. Applying the Test}

At the same time that the Comptroller approved the use of armored car messenger services, he also approved the use of "loan production offices" to solicit and service bank loans. ${ }^{110} \mathrm{He}$ ruled

108. In testifying before the House Committee on Banking and Currency, the President of the Independent Bankers' Association stated:

Multiple-outlet banking leads to concentration of control of bank credit and a lessening of competition. This occurs because larger banks can better afford to establish and promote additional offices. As large banks grow larger by this process, they move to a dominant position in banking markets. In this circumstance, smaller banks are placed at such a competitive disadvantage that ultimately many sell out to these large complexes, either voluntarily or by the force of the economic situation that they find themselves in.

Hearings on Federal Reserve Rulings Regarding Loan Production Offices and Purchase of Operating Subsidiaries of the House Comm. on Banking $\&$ Currency, 90th Cong., 2d Sess., ser. 9, pt. 2, at 3 (1968) [hereinafter cited as Hearings on Loan Production Offices].

109. For arguments that these assumptions are not valid, see OfFice of the Comptroller of the Currency, Studies in Banking Competition and the Banking STRUCTURE, pt. 2, 99-230 (1966).

110. 12 C.F.R. $\$ 7.7380$ (1974). The FRB followed the Comptroller's example and issued a ruling allowing state member banks to establish loan production offices as well. Id. $\$ 250.141(\mathrm{~h})$. There is no reported federal court litigation dealing with loan production offices, perhaps because Plant City has discouraged experimentation with them. But see Continental Bank \& Trust Co. v. Taylor, 14 Utah 2d 370, 384 P.2d (1963), holding than an arrangement with an automobile insurance agency to solicit automobile loans at its office was illegal branching under state law; the state's definition of "branch" is identical to that in the McFadden Act. 
that this activity did not constitute branching because an essential component of making a loan, the grant of approval, was performed at the main banking house. Whatever the reasonableness of the Comptroller's interpretation, ${ }^{111}$ it seems clear that, under the test developed in this comment, loan production offices should be regarded as branches.

Loan production offices would not have as great a pre-emptive tendency as traditional branches, since their functions are limited to soliciting and servicing loans. But if the credit requirements of a developing community were largely being met through such an office's operations, the chartering of a new bank there might be delayed for a significant period. A loan production office could also be used to invade an existing bank's service area, drawing away loan business that the local bank might otherwise obtain. The result would be "absentee credit control," which was one of the consequences that opponents of branching sought to prevent through the McFadden Act. ${ }^{12} \mathrm{~A}$ large bank with a large number of these offices for soliciting loan prospects would have a significant advantage over a bank that could not afford to rent and staff an equally large number of offices.

The facilities involved in Plant City present, on first inspection, a similar case. The alleged branches in that case were deposit machines and armored car messenger services, the latter being used to pick up cash from merchants and deliver cash to them, and also to service deposit machines. ${ }^{113}$ Like loan production

111. The chairman of the Federal Reserve Board, testifying before the House Committee on Banking and Currency, stated that loan production offices simply institutionalize a well-established banking practice:

[M]any large banks have for years sent traveling representatives to all points of the

Nation to solicit loan business. The loan production office gives the traveling representative-who does not approve loans or disburse money but merely engages in preliminary and servicing functions-a place to hang his hat.

Hearings on Loan Production Offices, supra note 108, at 31 . It can also be argued that if loan production offices are considered branches, use of bank credit cards should also be viewed as branching, since the consumer receives a "loan" at a retail store or restaurant every time he uses his card.

Opponents of the rulings authorizing loan production offices argue that the function of "making a loan" cannot be reduced to the bare acts of approval and disbursement of funds. They contend that the entire process of lending money must be considered, and that the limited functions of a loan production office must be seen in light of the competitive advantage it may confer. To an individual customer, they say, the origin of the check is unimportant, while the location where the loan application process begins is crucial. See generally id.; ILL ATT'y GEN. Op. No. S-512 (Sept. 14, 1972) (national banks may not establish loan production offices in Illinois).

112. See note 5I supra.

113. Armored cars could also be used for broader purposes, as virtual mobile teller windows. In Jackson v. First Nat'l Bank of Cornelia, 292 F. Supp. 156 (N.D. Ga. 1968), an armored car was used to service commercial accounts by picking up deposits, 
offices, these facilities could be expected to delay the establishment of new banks in developing areas, although-because they would perform a limited range of banking services-they would be unlikely to foreclose entirely the need for new banks. Furthermore, the facts of Plant City illustrated how these facilities might have promoted a concentration of economic power. First National began using them for its private benefit, to take business away from other financial institutions. Assuming that large banks would best be able to afford to employ deposit machines and armored cars, their use might well have enabled dominant banks to achieve an even larger share of local banking business.

But these facilities differ from loan production offices and traditional branches in an important respect. The latter two facilities are used for direct solicitation of new bank-customer relationships. Cooperative efforts by several banks to establish such offices would be unlikely, since the personnel staffing them would have to represent the interests of rival institutions at the same time. The armored cars and deposit facilities involved in Plant City, by contrast, perform only mechanical, prearranged transactions for a bank's existing customers. There seems to be nothing to prevent a group of small banks from pooling resources and, for instance, operating an armored car service for their mutual benefit. If all the banks in an area were able to take advantage of a messenger service, armored cars would no longer tend to promote monopoly and would not threaten the state's choice of banking structure. Thus, according to the statutory policies, participation in an armored car service under those circumstances should not be viewed as "branching." Indeed, if cooperative endeavor made armored car service available to all banks, the economic functions of the service would greatly resemble the functions now performed by independent commercial armored car companies-which apparently have never been considered harmful by the opponents of branch banking.

CBCTs can be subjected to a similar analysis, since a computer terminal system can be programmed to serve multiple banks with complete impartiality. The relationships for establishing a cooperative CBCT system already exist. ${ }^{114}$ Bank service corporations,

delivering cash, and providing a check cashing service for employees on payday. Armored cars performing these functions would present a stronger case for a finding that branching had occurred.

114. Cooperation is specifically envisioned in the Comptroller's current ruling: "To the extent consistent with the antitrust laws, national banks are permitted, but not required, to share such devices with one or more other financial institutions." Comptroller's Opinion at 44421 . 
set up to provide data processing services to a number of small banks, could perhaps expand their operations to include CBCTs. The correspondent bank system could be the vehicle for cooperation, with the large banks owning the system and their correspondents having access to it. Or the current bank credit card system could provide a basis for CBCT cooperation. ${ }^{115}$ Any such system would probably involve both the issuance of a universal card to address the terminal and the establishment of an automated clearinghouse to provide a communications link between the customer at the terminal and his own individual bank. Automated clearinghouses have already been developed; a project in California was specifically designed to allow use by all commercial banking houses, regardless of their technological capacities. ${ }^{116}$ In such a system, no bank would have an automatic advantage over any other in providing the most modern and convenient services for its customers. The state therefore could not reasonably prohibit CBCTs if its purpose was to protect small unit banks against large accumulations of capital. ${ }^{117}$ If a bank or group of banks could show that they had developed such a system in fact-or if the Comptroller mandated that kind of development by regulation-the terminals should not be characterized as branches.

At present, however, CBCTs are most likely to be installed and operated by individual banks for their own use. ${ }^{118}$ These banks gain at least a temporary advantage over their competitors by their ability to provide customers with more convenient service. Since the equipment is sophisticated and expensive, large banks are most likely to be the first users. A state opposed to branch banking has reason to fear that the CBCT systems of a few large banks might have the same effects on the banking structure that branches are thought to have. Thus, the current scene does not manifest the special circumstances that would be required to exempt from the McFadden Act's restrictions deposit and cash withdrawal operations performed at off-premises CBCTs.

Of course, this argument assumes that any impact on the bank-

115. See Baker, Antitrust and Automated Banking, 90 BANking L.J. 703 (1973).

116. Homrighausen, One Large Step Toward Less-Check: The California Automated Clearing House System, 28 Bus. Law. 1143 (1973).

117. Moreover, it would be difficult to characterize a terminal as the "branch" of any particular bank, since-like a telephone or mailbox-it could be used to communicate with all banks.

118. See Missouri ex rel. Kostman v. First Nat'l Bank in St. Louis, filed, No. 49456F(3), Cir. Ct. Mo., Jan. 6, 1975, removed and filed, Civil No. 113C(1), E.D. Mo., Feb. 18, 1975 (customer-operated CBCT owned by the First National Bank alone). 
ing structure in a state will be sufficient to trigger a broad reading of the statute and thus a classification of CBCTs as branches. It can be argued that the potential for cooperation among banks in establishing CBCTs and the correspondingly smaller impact that CBCTs may have on a state's banking structure justifies a conclusion that the Comptroller's interpretation-because not clearly unreasonable-is controlling. ${ }^{119}$ Given the judicial attitude manifested in Plant City, however, it would seem that even the threat of a de minimis competitive advantage for dominant banking institutions must be given determinative weight, so that the states' choices of banking structure may be preserved.

This conclusion does not mean, however, that states can or should restrict all uses of CBCTs by national banks. When retail stores utilize point-of-sale terminals to communicate with a bank, or to transfer funds incident to a purchase, "branching" is not at issue at all. In the first place, a facial reading of section 36(f) would not suggest that these functions are included within the federal definition. Second, there is no policy reason to extend the statute beyond its wording. The use of terminals to expedite third party payments is crucial to the success of the electronic payments system, ${ }^{120}$ and federal authorities have taken steps to assure that small banks will not be denied access to essential components of that system. ${ }^{121}$ Thus, the policy of the federal branch banking restrictions-to allow states to protect small, independent banks

119. In any consideration of the construction of banking legislation, the role of the Comptroller should not be overlooked. As administrator of the national banking system, the Comptroller is the official charged with the interpretation and enforcement of the National Bank Act, 12 U.S.C. $\S 1$ et seq. (1970). Ordinarily, therefore, the Comptroller's interpretive rulings defining the powers of national banks are upheld by the courts unless they are unreasonable constructions of the statute. Investment Co. Institute v. Camp, 401 U.S. 617, 626-27 (1971). Judicial deference to the Comptroller's rulings has been declining in recent years, however, as the Comptroller's office has sought to enlarge national bank activity beyond traditionally accepted limits. Four such interpretive rulings issued in the early 1960s by former Comptroller James Saxon-not including the one involved in Plant City-have been held invalid, in whole or in part, by the federal courts. See Investment Co. Institute v. Camp, supra (ruling allowed offering of a commingled investment account substantially equivalent to an open-end mutual fund); Arnold Tours, Inc. v. Camp, 472 F.2d 427 (Ist Cir. 1972) (ruling allowed national banks to operate a full-scale travel agency); Saxon v. Georgia Ass'n of Indep. Ins. Agents, 399 F.2d 1010 (5th Cir. 1968) (ruling allowed national banks to act as insurance agents); Port of N.Y. Auth. v. Baker, Watts, \& Co., 392 F.2d 497 (D.C. Cir. 1968) (ruling allowed national banks to purchase revenue bonds).

120. See note 4 supra.

121. The Justice Department has articulated an antitrust requirement "for equal access to an essential EFT [electronic funds transfer] facility." American Banker, May 20, 1974, at 1 . 
-is not threatened here. It might be added that the growth and development of the electronic payments system is important for an effective competitive national banking system. It will allow banks to escape from beneath an enormous load of paper, and it will provide the public with a more secure and convenient method of transferring funds. ${ }^{122}$ Furthermore, the Federal Home Loan Bank Board has begun to allow federal savings and loan associations to establish off-premises CBCTs and to transfer funds through them, so that customers can pay for goods and services out of interest-bearing accounts. ${ }^{123}$ If national banks are not allowed to develop their own CBCT systems to meet this competition, a serious imbalance between commercial banks and thrift institutions could result. One of the primary purposes of the McFadden Act was to maintain the strength of the national banking system; ${ }^{124}$ that statute should not now be construed to prevent banks from developing a technological innovation wholly unrelated to the concerns of the continuing branch banking controversy.

\section{Conclusion}

The technology of the customer-bank communication terminal provides an opportunity for financial institutions to develop a new

122. In 1972, twenty-five billion paper checks involving ninety-four million accounts were processed through the American banking system. 59 FED. RES. BULL. 279 (1973). By eliminating labor-intensive paper checking, the electronic payments system would reduce the costs of transfers to less than a penny per item. Id. at 875 . The system would also eliminate check "float," the time lag between the deposit and final payment of an instrument. But $f f$. note 16 supra. Furthermore, there would be a reduction in the use of cash and therefore in money-related crimes such as robbery; and, if identification techniques were perfected, crimes such as check forgery and passing bad checks would be completely eliminated. See Baker, Whatever Happened to the Checkless Society? 7 U. Mich. J. LAW REFORM 481 (1973).

Most of the major technological obstacles to the establishment of the electronic payments system have been overcome. Automated clearinghouses have been established in both Georgia (May 1973) and in California (October 1972), 59 FED. Res. BulL. 874 (1973), and point-of-sale terminals with the capacity to transfer funds have been established on an experimental basis in New York. N.Y. Times, Jan. 7, 1973, at 103, col. I. Yet consumer resistance remains a major obstacle. See Survey, supra note 4 at 1216.

Certain legal problems must also be resolved before the system can operate on a nationwide basis. These include protecting individual privacy, see Note, Government Access to Bank Records, 83 YALE L.J. 1439 (1974), and adapting the use of electronic impulses to the paper-check standards of the Uniform Commercial Code, see Dunne, Variation on a Theme by Parkinson or Some Propasals for the Uniform Commercial Cade and the Checkless Society, 75 YALE L.J. 788 (1966); Homrighausen, supra note 116.

123. Brooke, Problems in EFT Development Extend Beyond Considerations of Technology, American Banker, Nov. 20, 1974, at 1.

124. See text and note at note 48 supra. 
and perhaps better form of fund transfer. Whether state law restrictions on branch banking should be used to limit or prohibit the use of CBCTs by national banks depends on an interpretation of the policy behind the McFadden Act. The Supreme Court's Plant City decision emphasizes a policy of "competitive equality" between national and state banks. But application of a standard of competitive equality to the definition of a "branch" would require adoption of the state's definition of a "branch," a result explicitly rejected by the Plant City Court.

This comment has suggested that the branch status of an offpremises facility should instead be determined by asking whether the facility would interfere with the state's choice of banking structure. Since branching restrictions were designed by the states to prevent the concentration of capital in a few banks, the analysis must consider whether CBCTs lead to that result by giving a significant competitive advantage to larger and wealthier banks over smaller institutions.

CBCTs provide larger banks with somewhat less significant competitive advantages than traditional branches, primarily because they are limited in function and cannot directly attract new customers. And whatever advantage remains is mitigated to a certain extent by the potential for cooperation among smaller banks in establishing comparable systems. Nevertheless, since state legislators could reasonably conclude that the use of CBCTs by individual banks would affect the banking structure, such CBCTs must be considered branches within the meaning of the McFadden Act. But when smaller banks are allowed to participate in a cooperative CBCT project, the policy arguments against the use of CBCTs are no longer present, and the courts should not apply state law branching restrictions to CBCTs operated by national banks in that area. Finally, when CBCTs are used as point-of-sale terminals to communicate with a bank, or to transfer funds incident to a purchase, branching is not involved, and state law restrictions should not be interpreted to limit that use of CBCTs by national banks. 